\title{
INVESTIGATIONS ON THE CONCENTRATION OF THE NITROGENOUS METABOLIC PRODUCTS IN THE BLOOD UNDER PHYSIOLOGICAL AND PATHOLOGICAL CON- DITIONS
}

\author{
BY H. F. HÖST AND ROLF HATLEHOL
}

(From the State Hospital, Christiania, Medical Department A)

IT has been known for a long time that in certain kidney diseases nitrogenous metabolic products are retained in the organism, but only in the last decade, thanks to the improvement in technique, has it been possible to study the concentration of each metabolic product in the blood under physiological and pathological conditions. With his micro-methods Ivar Bang (1) and, later, many of his pupils have increased our knowledge of a number of the chemical bodies of the blood such as the chlorides, residual nitrogen, ${ }^{1}$ urea, fat, \&c. Otto Folin has gone farther than Bang with the methods he has continually improved during the last decade, making it possible especially to determine the quantitative relations of the nitrogenous bodies in the blood. In 1913 Folin (2) published his first 'System of Blood Analysis', by means of which a simultaneous estimation of residual nitrogen, urea, and uric acid could be made with a single sample of blood. Later, Folin and several other American workers have described simple methods of estimating the other constituents of the blood, such as creatinin, creatin, \&c. This development of the medico-chemical technique has stimulated a number of investigations on the chemistry of the blood, particularly by V. C. Myers (3) and his pupils. In these experiments the quantitative relations of the nitrogenous bodies in the blood in healthy people, and exhaustively also in a number of pathological conditions, have been elucidated. The technique employed, however, was not entirely free from error. The uric acid method usually involved a loss of about 10-15 per cent., and a number of creatinine estimations were carried out by methods which gave too high values (Greenwald and McGuire (4)).

It was further an important objection that a relatively large amount of blood was required for the simultaneous determination of residual $N$ and the better known nitrogenous bodies, more, indeed, than could be obtained from a single patient after much practice. In 1919 Folin (5), in company with his pupil $W u$, published a 'System of Blood Analysis', by which it is possible to estimate

${ }^{1}$ Residual nitrogen implies non-protein nitrogen.

[O.J. M., Oct., I92r.] 
residual $\mathrm{N}$, urea, uric acid, creatin, creatinin, and sugar with only 10 c.c. of blood. The sugar method-as the authors (6), among others, have drawn attention to-is not quite accurate, and Folin has subsequently modified it. But apart from this, Folin's last 'System' constitutes a masterpiece in medicochemical technique. In his uric acid method, particularly, Folin has succeeded in eliminating the difficulties of the method which for a number of years bave been the object of futile research.

In the near future Folin's technique will undoubtedly obtain a wide application clinically because its simplicity and the relatively small quantity of blood required make it extremely suitable for the investigation of the concentration of the various nitrogenous metabolic products in the blood under pathological conditions. We, therefore, thought it would be of interest to investigate the nitrogenous constituents of the blood, with the help of Folin's 'System', in a larger number of cases; and we have employed partly healthy people, convalescents, and patients suffering from diseases in which the nitrogenous products in the blood could be presumed to be normal, and partly diabetics and patients suffering from kidney disease. In a number of these, particularly the renal patients, we have further investigated the excretion of phenolsulphonephthalein.

Before beginning our investigations we undertook a number of analyses of solutions of pure urea to control the residual $\mathrm{N}$ and the accuracy of the urea method. Of these controls the following may be tabulated:

A 1 per cent. urea solution was prepared. This was analysed by the residual $\mathrm{N}$ method, and also by the urea method.

The residual $N$ method gave the following results in three estimations:

1. 0.474 pro mille $\mathrm{N}$

2. $0.465 ", ", \quad$ " Calculated, 0.466 pro mille.

The urea method gave the following results in three estimations :

1. 0.454 pro mille $\mathrm{N}$

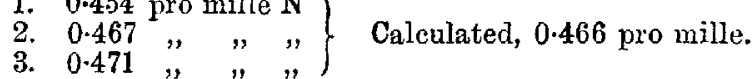

An estimation of the residual $\mathrm{N}$ in the blood was next made before and after the addition of a definite amount of urea.

Blood, 1. Residual N. In two analyses 0.392 pro mille was found both times. The same blood, with the addition of 1 pro mille urea, gave 0.89 against 0.86 pro mille calculated.

Blood, 2. Residual N. In two analyses $0 \cdot 44$ and $0 \cdot 43$ pro mille were found. The same blood, with the addition of 1.41 pro mille $N$ in the form of urea, in two estimations gave 1.87 and 1.82 against 1.83 and 1.84 pro mille calculated.

From these controls it follows that Folin's residual $N$ and urea methods are very accurate, as the error does not exceed 3-4 per cent.

The result of the sugar estimation in the blood, as mentioned above, is not absolutely accurate. The following estimations were made, however, before we 
were aware of the error of the method, but since it is not great we have included the results obtained.

TABLE I.*

Healthy People and Patients suffering from Various Diseases.

\begin{tabular}{|c|c|c|c|c|c|c|c|c|c|}
\hline Name. & Sex. & Age. & Diagnosis. & $\begin{array}{c}\text { Residual } \\
\text { N. }\end{array}$ & $\begin{array}{l}\text { Urea } \\
\text { N. }\end{array}$ & Urea. & $\begin{array}{c}\text { Creati- } \\
\text { nin. }\end{array}$ & Sugar. & $\begin{array}{l}\text { Phenol- } \\
\text { sulphone- } \\
\text { phthalein. }\end{array}$ \\
\hline E. B. & $\mathrm{M}$ & 22 & Nil & 28.7 & 11.5 & $2 \cdot 4$ &.- & 110 & \\
\hline E. K. & $M$ & 24 & , & 31.4 & 13.9 & $4 \cdot 1$ & $1 \cdot 0$ & 109 & 60 \\
\hline M. $\mathrm{H}$. & $F$ & 28 & $"$ & 36.0 & $18 \cdot 9$ & $3 \cdot 9$ & $1-2$ & 98 & \\
\hline H. M. & $\mathrm{M}$ & 26 & & 26.9 & $10-5$ & $3 \cdot 3$ & 1.2 & 111 & \\
\hline H. B. & M & 54 & Cancer & 32.0 & $14 \cdot 2$ & $4 \cdot 3$ & & 109 & \\
\hline A. $\mathrm{B}$. & M & 45 & Pernicious & $33 \cdot 1$ & 11.8 & $4 \cdot 6$ & $1 \cdot 1$ & 110 & \\
\hline J. A. & F & 62 & $", "$ & $23 \cdot 7$ & $16 \cdot 2$ & $2 \cdot 8$ & $1 \cdot 1$ & 105 & 80 \\
\hline P. N. & $\mathrm{MI}$ & 41 & ,", & 30.9 & 19.7 & & 1.0 & 100 & \\
\hline o. B. & $\mathrm{F}$ & 39 & & 26.9 & $15 \cdot 1$ & 4.0 & $1 \cdot 0$ & 106 & \\
\hline o.s. & $\mathrm{M}$ & 58 & Polyneuritis & 30.8 & 11.5 & $2 \cdot 5$ & $1 \cdot 1$ & 100 & \\
\hline G. A. & $\mathrm{M}$ & 60 & Abdominal & 37.8 & $22 \cdot 2$ & $3 \cdot 6$ & $1 \cdot 2$ & 145 & \\
\hline K. S. & M & 25 & Sciatica & 34.0 & 14.2 & 2.5 & & 105 & \\
\hline O. R. & M & 30 & $\begin{array}{l}\text { Tuberculous } \\
\text { peritonitis }\end{array}$ & $39 \cdot 0$ & $19 \cdot 2$ & $2 \cdot 8$ & $1 \cdot 3$ & 100 & \\
\hline M. E. & M & 70 & Cancer & 41.0 & 20.9 & $3 \cdot 3$ & $1: 1$ & 134 & \\
\hline
\end{tabular}

In healthy people, and in patients suffering from various diseases in whom the nitrogenous substances of the blood a priori were presumed to be normal, we have found (in fourteen individuals) the following limiting values, as will be evident from Table I :

\begin{tabular}{|c|c|c|c|c|}
\hline & Minimum. & Maximum. & \multirow{2}{*}{\multicolumn{2}{|c|}{ Mg. per 100 c.c. blood }} \\
\hline Residual N & 23.7 & 41 & & \\
\hline Urea $\mathrm{N}$ & $10 \cdot 5$ & $22 \cdot 2$ & , , , &, \\
\hline Uric acid & $2 \cdot 4$ & $4 \cdot 6$ & ", & ," \\
\hline Creatinin & 1.0 & $1 \cdot 3$ & ", & ," \\
\hline
\end{tabular}

The values agree, on the whole, quite well with those found previously. The range of variation of the urea $\mathrm{N}$, however, is rather larger than is usually seen. Similarly, the upper limit of the normal uric acid concentration is higher than hitherto assumed. Folin points out that his latest method gives higher values than the earlier ones, and he thinks it is because some uric acid was lost in the earlier methods. We have not found a greater creatinin concentration than 1.3, while many earlier investigators (Folin (7), 1914, and Myers (8), 1916) found up to 2.5 in healthy individuals.

In eight diabetics (see Table II), in some of whom the blood-sugar was considerably increased, we found the concentration of the nitrogenous bodies in the blood to be normal, with the exception that the uric acid concentration in one case rose to $5 \cdot 8$, and that the creatinin values on an average were much greater than normal, but lower than the upper limit fixed by Folin and later by Myers. 
TABLE II.

Diabetes.

Name. Sex. Age. Residual N. Urea N. Uric Acid. Creatinin. Sugar.

\begin{tabular}{|c|c|c|c|c|c|c|c|}
\hline A. $\mathrm{H}$. & $\mathbf{F}$ & 20 & 26.4 & $11 \cdot 3$ & 1.8 & 1.5 & 286 \\
\hline & & $\overline{-}$ & $24 \cdot 1$ & 8.9 & $1 \cdot 9$ & $1 \cdot 4$ & 276 \\
\hline S. & M & 65 & lost & 13.5 & $1 \cdot 3$ & 1.5 & 109 \\
\hline J. S. & M & 55 & 27 & $13 \cdot 3$ & $2 \cdot 2$ & 1.5 & 113 \\
\hline O. H. & $\mathrm{F}$ & 45 & $38 \cdot 3$ & $17 \cdot 0$ & $3 \cdot 6$ & 1.4 & 200 \\
\hline M. 0 . & F & 55 & $34 \cdot 3$ & 15.2 & $3 \cdot 2$ & $1 \cdot 6$ & 267 \\
\hline I. J. & MI & 22 & $24 \cdot 6$ & $12 \cdot 1$ & $2 \cdot 8$ & 1.3 & 298 \\
\hline S. F. & $\mathrm{F}$ & 18 & $34-3$ & $12 \cdot 1$ & $5 \cdot 8$ & lost & 250 \\
\hline
\end{tabular}

Table III

Renal Disense.

\begin{tabular}{|c|c|c|c|c|c|c|c|c|c|c|}
\hline Name. & Sex. & Age. & Diagnosis. & $\begin{array}{c}\text { Blood. } \\
\text { pressure. }\end{array}$ & $\begin{array}{l}\text { Residual } \\
\text { N. }\end{array}$ & Urea $N$. & $\begin{array}{l}\text { Uric } \\
\text { Acid. }\end{array}$ & $\begin{array}{l}\text { Creati- } \\
\text { nin. }\end{array}$ & Sugar. & $\begin{array}{l}\text { Phenol- } \\
\text { sulphone } \\
\text { phthaleir }\end{array}$ \\
\hline G. 0 . & $\mathbf{F}$ & 43 & Nephrosis & 110 & $33 \cdot 2$ & 18.1 & $2 \cdot 3$ & 1.2 & 113 & 65 \\
\hline G. S. & $\mathbf{M}$ & 17 & , & 115 & $28 \cdot 3$ & 9.2 & 3.8 & $1 \cdot 0$ & 109 & 80 \\
\hline H. S. & $\mathbf{F}$ & 54 & & 110 & $27 \cdot 5$ & 13.0 & 23 & 1.9 & 95 & 73 \\
\hline A. J. & $\mathbf{F}$ & 57 & Nephro-sclerosis & 165 & 40.0 & 19.5 & $2 \cdot 2$ & 1.7 & 97 & 53 \\
\hline S. J. & $\mathrm{F}$ & 78 & , & 210 & $39 \cdot 1$ & 14.0 & 4.0 & 1.2 & 137 & \\
\hline A. B. & $F$ & 54 & & 200 & $36 \cdot 6$ & 17.0 & $3 \cdot 6$ & 1.6 & 93 & 60 \\
\hline J. H. & M & 26 & Nephritis & 130 & $37 \cdot 1$ & 15.8 & $5 \cdot 2$ & - & 114 & 46 \\
\hline $0 " \mathrm{~T}$ & & & & & & $11 \cdot 8$ & $6 \cdot 1$ & - & 108 & \\
\hline & $M$ & 22 & Nephritis & 135 & $31 \cdot 2$ & $11 \cdot 8$ & $4 \cdot 5$ & - & 106 & 70 \\
\hline P. & M & 20 & $"$ & 135 & 29.5 & $16 \cdot 6$ & $3 \cdot 6$ & - & 122 & 64 \\
\hline I. & F & 22 & 3 & 130 & $52 \cdot 0$ & $38 \cdot 2$ & $3 \cdot 0$ & $1 \cdot 3$ & 97 & 26 \\
\hline & & & & & & 34.4 & $2 \cdot 3$ & 1.8 & 102 & - \\
\hline & $\mathbf{M}$ & 30 & Nephritis & 115 & 37.1 & $17 \cdot 8$ & $5 \cdot 1$ & 1.5 & 95 & - \\
\hline F"” & $M$ & 10 & Nombuiti & & & $13 \cdot 7$ & $2 \cdot 9$ & 1.2 & 100 & - \\
\hline A. $F$. & $\mathrm{M}$ & $\begin{array}{l}40 \\
36\end{array}$ & Nepnritis & 115 & 35.0 & $16 \cdot 6$ & 4.0 & 1.1 & 102 & - \\
\hline & & & $"$ & 120 & $40 \cdot 0$ & $16 \cdot 8$ & $3 \cdot 2$ & 1.3 & 93 & -- \\
\hline
\end{tabular}

In the diagnosis of kidney disease (see Table III) the classification devised by Volhard and Fahr (9) has been used. Like all other classifications this has its limitations, partly because nature is not schematic but displays all possible intermediate forms. On the whole, however, Volbard and Fahr's elassification of renal diseases is undoubtedly a great step forward, as is fully proved by the wide recognition their work has received in the course of a few years from almost every quarter.

In three patients suffering from nephrosis and three suffering from nephrosclerosis the nitrogenous bodies were found to be normal in concentration.

Of the seven nephritis cases, six were getting well again. In these the residual $\mathrm{N}$ and urea values were normal, but two of them showed some increase in the amount of uric acid. One patient, I. K., showed symptoms of chronic nephritis in the second stage, and in her case a considerable increase of residual $\mathrm{N}$ and urea $\mathrm{N}$ was found in two tests, while the uric acid and creatinin concentrations were normal.

Myers and his pupils contend the kidneys are able to concentrate creatinin much more easily than uric acid, urea occupying an intermediate position, from 
which one would expect uric acid would be the first to be retained when the kidneys became impaired in function, followed by urea-and creatinin not until the disease was farther advanced. In the extensive material dealt with by Myers and his pupils there appears to be a 'staircase effect' when the blood analyses of nephritis patients, whose disease is fairly well advanced, are compared. There are exceptions to the rule, however, since--as Myers himself points out-nephritis cases oceur with retention of residual $\mathrm{N}$ and urea $\mathrm{N}$ but no increase of uric acid. As already mentioned we had two among the seven patients who showed an increase of the uric acid concentration only, while one had an increase of residual $\mathbf{N}$ and urea $\mathrm{N}$, but not of uric acid. The phenolsulphonephthalein excretion was considerably lowered in the patient with increased residual $\mathrm{N}$ and somewhat low in the patient J. H., who bad an increase of uric acid only.

In addition to the above investigations in a total of thirty-four healthy and diseased people, we have had the opportunity of following the concentration of the nitrogenous metabolic products in the blood for a longer period, until death took place, in four patients who suffered from various kidney diseases, but all of whom had typical symptoms of uraemia.

\section{TABLE IV.}

No. 1. O. O. Man, 32 years old. Diagnosis: Pyelonephritis.

Admitted May 7. Died May 18.

\begin{tabular}{|c|c|c|c|c|c|c|c|}
\hline Day. & Residual N. & Urea $\mathbf{N}$. & Uric Acid. & Creatinin. & Sugar. & $\begin{array}{l}\mathrm{CO}_{2} \text { in } \\
\text { Blood. }\end{array}$ & $\begin{array}{l}\text { Blood- } \\
\text { pressure. }\end{array}$ \\
\hline May 10 & $220 \cdot 0$ & 167 & $8 \cdot 6$ & $20 \cdot 3$ & $0 \cdot 14$ & - & 150 \\
\hline$" \quad 12$ & $251 \cdot 6$ & $197 \cdot 3$ & $8 \cdot 7$ & 20.5 & $\begin{array}{l}0.14 \\
0.14\end{array}$ & - & 160 \\
\hline $\begin{array}{ll}" 14 & 14 \\
" & 17^{*}\end{array}$ & 300 & 250 & $10 \cdot 5$ & $\begin{array}{l}23 \cdot 0 \\
23 \cdot 0\end{array}$ & - & 20 & 100 \\
\hline
\end{tabular}

The first of these patients was a man, 32 years old, whose mother and brother had died of tuberculosis. At the age of 14 he had tuberculosis of the spine, and ten years ago he was in Molde Hospital with 'kidney disease', from which he is said to have recovered. He was then well until two months before admission to hospital, when he became increasingly short of breath, oedema appearing at the same time.

On admission, 7.5.20, he was pale, rather oedematous, and complained of headache. Albumin, masses of pus cells, and numerous staphylococci were found in the urine, but no casts. He vomited frequently and was rather restless, but had no fits. The blood-pressure was 130-150. During his last days he became comatose, dying in coma on 18.5.20. The amount of urine for the first week was 500-600 e.c., but then sank to 300 and 200 c.c. During the last twentyfour hours the patient passed no urine. Double pyelonephritis was found at the autopsy.

The blood of this patient was tested for the last eight days before death. As will be seen from the first test, the residual $\mathrm{N}$ was already $220 \mathrm{mg}$. and increased steadily until, about twelve hours before death, it reached a value of $300 \dot{\mathrm{mg}}$. The urea increased parallel with the residual $\mathrm{N}$, the first value being $167 \mathrm{mg}$. and the last $250 \mathrm{mg}$. The amount of uric acid rose from 8.6 to $10.5 \mathrm{mg}$. The creatinin in the first test was already unusually high, $20.3 \mathrm{mg}$., and rose to $23 \mathrm{mg}$. The alkali reserve was investigated once only, at the last blood test 
twelve hours before death. It was then 20 ; that is to say, as low as it is found in diabetic coma. Therefore 25 grm. sod. bicarb. were administered by the mouth, divided into several doses, which he retained, but it did not seem to have any influence on his condition.

\section{TABLe V.}

No. 2. A. B. Man, 42 years old. Diagnosis : Malignant nephro-sclerosis. Admitted May 19. Died May 26.

\begin{tabular}{|c|c|c|c|c|c|c|c|}
\hline Day. & Residual N. & Urea $\mathrm{N}$. & Uric Acid. & Creatinin. & Sugar. & $\begin{array}{l}\mathrm{CO}_{2} \text { in } \\
\text { Blood. }\end{array}$ & $\begin{array}{l}\text { Blood- } \\
\text { pressure. }\end{array}$ \\
\hline May 21 & 132 & 112 & $7 \cdot 6$ & $10 \cdot 0$ & 0.12 & 46 & $\frac{280}{180}$ \\
\hline $\begin{array}{l}\quad 22 \\
24\end{array}$ & 160 & 134 & $7 \cdot 6$ & $12 \cdot 8$ & 0.125 & 51 & 100 \\
\hline$" \quad 24$ & 240 & 200 & $7 \cdot 5$ & $19 \cdot 2$ & 0.133 & 41 & $\begin{array}{l}2850 \\
150 \\
0\end{array}$ \\
\hline $\begin{array}{l}25 \\
8 \text { a.m. }\end{array}$ & 275 & 253 & & & 0.137 & 37 & 200 \\
\hline $\begin{array}{l}\text { May } 25 \\
7 \mathrm{pm}\end{array}$ & 304 & 265 & - & $21 \cdot 5$ & - & 28 & - \\
\hline May 26 & 320 & 270 & $9 \cdot 5$ & $22 \cdot 0$ & 0.146 & 30 & - \\
\hline $\begin{array}{r}\text { May } 26^{*} \\
6 \text { p.m. }\end{array}$ & 320 & 280 & $9 \cdot 0$ & $26 \cdot 8$ & - & 30 & 210 \\
\hline
\end{tabular}

Patient No. 2 was a man 42 years of age who had a marked tuberculous taint in his family, four of his brothers and sisters having died of tuberculosis. $\mathrm{He}$ himself had been well up to the summer of 1918, when he began to get headache, which later became almost incessant and tended to get worse. He was admitted to the medical wards on two occasions-six weeks in the spring of 1919 and seven days in May, 1920.

During his first stay in hospital he had a greatly increased blood-pressure, 230-250, and a trace of albumin and casts in the urine. The headache and albumin disappeared in hospital. After autumn and winter the beadache started anew, but ho was at work in an office up till four days before admission to hospital. During his second stay in hospital the most important symptoms were headache, vomiting, apathy, sleepiness, and coma which ended in death. An autopsy was not allowed. There was no oedema and no fits. The urine contained considerable quantities of albumin as well as red blood-cells and casts. The amount of urine, as appears in the table, was seen in the first few days much decreased, and during the last days none was passed. Its volume, specific gravity, and content of sodium chloride and urea were as follows:

$\begin{array}{cccccc}\text { Date. } & \text { Amount. } & \text { Sp. gr. } & \text { NaCl \%. } & \text { Urea \%. } & \\ \text { May 21-2 } & 180 \text { c.c. } & \mathbf{1 0 2 5} & 0.92 & 2 \cdot 14 & \\ \# 22-3 & 230, " & \mathbf{1 0 1 2} & 0.16 & 1.15 & \text { catheter } \\ " 23-4 & 195, " & 1011 & 0.19 & 1.05 & \text { " }\end{array}$

In November, 1919, one of us (Höst) estimated the residual $\mathrm{N}$, which was normal, but on admission it was, as will be seen, considerably increased and rose in the course of the following five days extremely rapidly, being $320 \mathrm{mg}$. five hours before death. The urea $N$ ran parallel with the residual $N$ and reached a value of $280 \mathrm{mg}$. The uric acid only rose from 7.6 to $9 \mathrm{mg}$., but the creatinin increased rapidly from 10 to $26.8 \mathrm{mg}$. The alkali reserve sank from about normal to roughly 30 , and the blood-pressure, which in the first few days was about 250, declined during the last days to 200.

The third patient was a woman of 54, who had previously been healthy, but three months prior to admission began to feel languid and tired, and suffered from thirst. During the ten days she was in hospital the most important 
symptoms were dyspnoea, headache, nausea, vomiting, sleepiness, and coma ending in death. The urine contained albumin and casts but no red blood-cells. There was no oedema and no fits. The blood-pressure was about 200. The amount of urine for the first few days was 500-600 c.c., but sank towards the end to a couple of hundred. No autopsy was allowed.

\section{TABLE VI.}

No. 3. M. H. Woman, 54 years of age. Diagnosis : Malignant nephrosclerosis.

Admitted July 3. Died 13.7.20.

Day. Residual N. Urea N. Uric Acid. Creatinin. $\mathrm{CO}_{2}$ in Blood. Blood-pressure.

\begin{tabular}{|c|c|c|c|c|c|c|}
\hline $\begin{array}{cc}\text { July } & 11 \\
, & 12 \\
" & 13^{*}\end{array}$ & $\begin{array}{l}100 \\
144 \\
213\end{array}$ & $\begin{array}{r}85 \\
130 \\
200\end{array}$ & $\begin{array}{r}4.0 \\
4.6 \\
10.0\end{array}$ & $\begin{array}{l}6.0 \\
10.8 \\
20\end{array}$ & $\begin{array}{l}30 \\
30 \\
30\end{array}$ & $\begin{array}{l}200 \\
210 \\
200\end{array}$ \\
\hline
\end{tabular}

The nitrogenous constituents of the blood were investigated during the last three days the patient was alive. The last sample of blood was taken two hours before death. All the nitrogenous substances rose very rapidly, but the residual $\mathbf{N}$ and the urea $\mathbf{N}$ did not reach such high values as in the preceding patients. The alkali reserve was in this case also down to 30.

\section{TABLe VII.}

No. 4. M. F. Man, 21 years of age. Diagnosis : Chronic nephritis. Admitted, first time 7.2.20. Discharged 7.5.20. " second time 10.10.20. Died 24.11.20.

First Admission to Hospital.

\begin{tabular}{|c|c|c|c|c|c|}
\hline Day. & Residual $\mathrm{N}$. & Urea $N$. & Urie Acid. & Creatinin. & Blood-pressure. \\
\hline $\begin{array}{l}\text { Mar. } 23 \\
\text { Apr. } 7\end{array}$ & $\begin{array}{l}69 \\
72 \\
75\end{array}$ & $\begin{array}{l}47 \\
45\end{array}$ & $\begin{array}{l}1.9 \\
2.7\end{array}$ & $\begin{array}{l}2 \cdot 1 \\
3 \cdot 0\end{array}$ & 135 \\
\hline $\begin{array}{ll}" & 23 \\
, \quad 30\end{array}$ & $\begin{array}{l}75 \\
77\end{array}$ & $\begin{array}{l}60 \\
60\end{array}$ & $\overline{5.0}$ & $\begin{array}{l}3 \cdot 0 \\
3 \cdot 0\end{array}$ & $\begin{array}{l}150 \\
140\end{array}$ \\
\hline
\end{tabular}

Second Admission to Hospital.

\begin{tabular}{|c|c|c|c|c|c|c|c|}
\hline \multicolumn{2}{|c|}{ Day. } & $\begin{array}{l}\text { Residual } \\
\text { N. }\end{array}$ & $\begin{array}{c}\text { Urea } \\
\text { N. }\end{array}$ & $\begin{array}{l}\text { Uric } \\
\text { Acid. }\end{array}$ & Creatinin. & $\mathrm{CO}_{2}$ & Blood-pressure. \\
\hline \multirow{6}{*}{$\begin{array}{l}\text { Oct. } \\
", \\
", \\
",\end{array}$} & 11 & 235 & 188 & 8.4 & 10 & 44 & 150 \\
\hline & 14 & 240 & 190 & 10 & 10 & 36 & 150 \\
\hline & 16 & 240 & 200 & 9 & 10 & 36 & 一 \\
\hline & 21 & 236 & 194 & 10 & 9 & 46 & 140 \\
\hline & & 235 & 205 & 13 & 9 & $\ldots \quad 29$ & $30 \mathrm{grm}$. sod. bicarb. from \\
\hline & 28 & 230 & 200 & 12 & 10 & $\begin{array}{r}70 \mathrm{clock} 54 \\
52\end{array}$ & $\begin{array}{l}11 \text { to } 60 \mathrm{clock} \\
150\end{array}$ \\
\hline \multirow{6}{*}{$\begin{array}{c}\ddot{N}_{\text {ov. }} \\
", \\
" \\
" \\
",\end{array}$} & .5 & 240 & 203 & 12 & 9 & 48 & \\
\hline & 12 & 256 & 210 & 14 & 9 & 42 & 150 \\
\hline & 15 & 265 & 215 & 17 & 9 & 40 & - \\
\hline & 18 & 341 & 271 & 19 & 14 & 50 & 150 \\
\hline & 23 & 335 & 275 & 26 & 19 & 50 & 150 \\
\hline & & 350 & 279 & 26 & 20 & & \\
\hline & & & & $\mathrm{T}_{\mathrm{x}}$ & & & \\
\hline
\end{tabular}

The last of these patients has been the best observed, and therefore possesses the greatest interest. It was a man, 21 years old, who was twice in hospitalthree months in the spring of 1920 and six weeks in the autumn of the same 
year. He had been well till three or four weeks before the first admission, when he began to suffer from tiredness and thirst, for which he consulted a doctor, who discovered albuminuria. During the first stay in hospital the patient had no other symptoms than tiredness, apart from albuminuria, haematuria, casts in the urine, and a rather increased blood-pressure, 130-150.

The nitrogenous bodies of the blood were estimated four times during the first stay in bospital, and showed, as may be seen, on the first test somewhat increased residual $\mathbf{N}$ and urea, but the uric acid and creatinin were normal. The three following determinations showed a distinet but not a very great rise in the amounts of all the constituents, the uric acid and creatinin exhibiting a pathological increase.

On discharge from hospital, May 7, 1920, the patient was fairly well and was able to do some work for four months. In the beginning of September he again had to give up work on account of feeling languid and increasing oedema. The most important symptoms during the second visit to hospital were oedema, marked dyspnoea, continual vomiting, headache, pericarditis, dry pleurisy, and retinitis. The urine contained albumin in varying quantities, casts, and now and again blood. In the last few days of life the patient became somnolent and died in coma. At the autopsy, double contracted kidney was found.

The blood examinations showed that the nitrogenous bodies remained almost unchanged in the first month, but increased very rapidly in the last ten days and, as will be seen, reached very high values. Twenty-four hours after death an autopsy was made, and blood was collected from the heart which, on analysis, was found to contain the same quantities of residual $\mathrm{N}$, urea, uric acid, and creatinin as the blood taken immediately before death. The demonstration that the nitrogenous constituents of the blood are not altered in the first twentyfour hours after death is of no small interest because it renders the diagnosis of uraemia possible after death. The alkali reserve differs somewhat from the other cases. In the first fortnight it varied between 36 and 44, and when, on October 25, it had fallen to 29 the patient received $30 \mathrm{grm}$. sodium bicarbonate between 11 and 6 o'clock. At 7 o'clock another test showed the alkali reserve had risen to 54, and remained stationary for the whole of the next month at about 50 .

The urine of this patient was interesting. From October 14, until the patient died, the amount of urine, the specific gravity, urea, and chlorides were daily recorded. The quantity of urine passed daily from October 14 to November 10 was between 1 and 2 litres, but on November 11 it suddenly dropped to 500, and later it reached from 200 to 300 c.c. per diem. As will be seen this fall in the diuresis coincides fairly accurately with the rapid increase in the nitrogenous bodies of the blood. The specific gravity of the urine during the whole of the second stay in hospital was 1,010-1,011, that is to say, it had the same molecular concentration as the blood. The patient showed signs of hypostenuria or, as it has also been called, isostenuria, which, as is well known, is characteristic of the third stage of nephritis. The concentration of urea in the urine varied from 0.8 to $0 \cdot 2$ per cent., rising somewhat in the last week of the patient's life. The chloride concentration showed just the opposite, being about 1 pro mille at first, but during the last week it fell to 0.2 to 0.3 pro mille.

Our investigations on the nitrogenous bodies of the blood in uraemia comprise, as will be seen, only four patients, but the results should nevertheless be of interest because each patient had been examined fairly thoroughly.

Only with the aid of Folin's methods has it been possible to determine the residual $\mathrm{N}$, urea $\mathrm{N}$, uric acid, and creatinin simultaneously in a small sample of blood, and therefore the majority of estimations previously carried out in Europe, and especially Germany, relate only to a few nitrogenous bodies in the blood. In America a considerable number of investigations on the chemistry of 
the blood in uraemia have been undertaken in the course of a few years, especially in Myers' laboratory at the Post-Graduate Hospital, New York, but the patients were, as a rule, not followed from day to day up till death, as we have done.

It would be interesting to know whether the results of these tests throw any light on the various problems connected with uraemia, and we will therefore proceed to discuss our investigations with reference to the cause of the marked accumulation of nitrogenous metabolic products in the blood in uraemia, and see if our material affords any basis for a causal relation between the accumulated products and the uraemic symptoms. When metabolic products are retained in the body the cause may be a diminished excretion, an increased formation, or a combination of the two. In uraemia we know that in consequence of renal disease there is deficient excretion. Our material also illustrates this point, as there was always a marked diminution in the amount of urine or even anuria preceding or running parallel 'with a pronounced increase of the nitrogenous metabolic products in the blood.

Some authors, such as Richter and von Noorden (10), maintain, however, that in uraemia a considerable increase in the production of nitrogenous bodies can take place, which they believe to be due to a greatly increased breaking down of the tissue proteins in consequence of the uraemia. In three of our uraemia patients we have tried to obtain an explanation of the amount of urea formed in the body. In such an inquiry it is necessary to know the amount of urea the patient normally produces on the given diet, the quantity of water in his tissues, the relation between the amount of urea in the blood and the total amount in the body, and the quantity of urea excreted.

We know that an adult on an ordinary diet excretes $15-30 \mathrm{grm}$. urea in twenty-four hours, but while fasting the excretion is much smaller, and our uraemic patients' diet closely approximated to the latter, because only small quantities of sloppy food and water were taken on account of nausea and vomiting. In order to guard against too low an estimate of the production of urea we have adopted a daily value of $15 \mathrm{grm}$.

The second factor, the water content of the organism, is comparatively well known under physiological conditions, but in uraemia, where water is retained, the estimation of the total fluid content is very uncertain.

As regards the relation between the urea concentration of the blood and tissues, Marsball and Mavis (11) were probably the first to show that urea is not accumulated in the blood only, but is found fairly evenly distributed in the organism, which has later been confirmed by many others.

It is only the fourth factor, the excretion of urea, that can be accurately determined, provided the patient has no diarrhoea which would occasion the excretion of large amounts of urea by the intestine.

There are therefore various difficulties in the way of determining the amount of urea formed in uraemia, and it can only be large deviations from the normal that there is any hope of demonstrating by such estimations. 
In patient No. 4 the daily excretion of urea was determined. If we take the last fourteen days the pationt lived for the purpose of calculation, when the greatest increase of the urea in the blood was found, we obtain a urea excretion of $60 \mathrm{grm}$. altogether. If it is assumed that under physiological conditions $15 \mathrm{grm}$. of urea would be formed in twenty-four hours, then for fourteen days the amount works out at $210 \mathrm{grm}$. The $60 \mathrm{grm}$. excreted by the patient must be subtracted from this, leaving about $150 \mathrm{grm}$. urea as the amount retained by the patient in this fortnight. The total volume of fluid in this patient was difficult to estimate on account of the oedema, but as his weight was $65 \mathrm{~kg}$. the fluid in his body may be reckoned as about $50 \mathrm{~kg}$. $150 \mathrm{grm}$. of urea contain about $70 \mathrm{grm}$. urea $\mathrm{N}$, and this $70 \mathrm{grm}$. $\mathrm{N}$ distributed over $50 \mathrm{~kg}$. fluid corresponds to $120 \mathrm{mg}$. $\mathrm{N}$ per 100 c.c. blood. As will be seen the residual $N$ of the blood rose about $70 \mathrm{mg}$. in this fortnight, which agrees fairly well with the calculated amount when it is considered the calculation is made for the whole period of fourteen days, and consequently a trifling error each day will add up to a considerable one.

Patient No. 2 weighed $65 \mathrm{~kg}$, and as he had no oedema his total volume of fluid can be estimated at about $40 \mathrm{~kg}$. During the period May 21-24, that is to say, immediately before he died, the daily excretion of urea was determined and was found to be $8.55 \mathrm{grm}$. Assuming again a daily urea production of $15 \mathrm{grm}$., the amount retained was $15 \times 3=45-8.55=$ about $36 \mathrm{grm}$. urea, corresponding to about $16.8 \mathrm{grm}$. N. $16.8 \mathrm{grm}$. $\mathrm{N}$ in $40 \mathrm{~kg}$. fluid is roughly $42 \mathrm{mg}$. per 100 c.c. blood. As a matter of fact the urea $\mathrm{N}$ in this period rose from 112 to $200 \mathrm{mg}$., that is, $88 \mathrm{mg}$., in other words twice as much as calculated. This patient therefore had a very marked production of urea.

The blood of patient No. 3 was tested during the last three days of life. The last sample was taken two hours before death. No urine was passed in the last twenty-four hours, and in the previous twenty-four hours the amount was only 200 c.c. The excretion of urea in the last two days was therefore extremely small and can be neglected in the calculations. The patient weighed $65 \mathrm{~kg}$. and had no oedema. Reckoning in the same manner as before, the urea $\mathrm{N}$ in the blood during these two days should have risen about $35 \mathrm{mg}$., but in reality it increased $115 \mathrm{mg}$., therefore more than three times as much as calculated. A similar marked increase took place in the case of residual $N$, uric acid, and creatinin.

It is clear the accumulation of urea in the organism in cases of uraemia proceeds with very different rapidity, and this is only dependent upon its excretion in a very subordinate degree. As the nourishment taken by these patients during the period of observation was practically the same, and was decidedly insufficient for the needs of the body, the varying rapidity with which the accumulation took place must have been to a large extent due to the fact that the patients metabolized their body proteins in very different degrees.

The reason why a considerably greater breaking down of protein occurs in some uraemic patients than in others is not at first sight clear. But we must not omit to point out the fact that in the patient in whom the urea production 


\section{NITROGENOUS METABOLIC PRODUCTS IN THE BLOOD}

corresponded so well with the calculated quantity there was hardly any acidosis, while in the two others, in whom it was strikingly large, there was marked acidosis. In this connexion we must remember Senator's view that in uraemia abnormal protein metabolism is going on with consequent acidosis. How far this conception is true we are not in a position with our scanty and, as far as this question is concerned, too superficial investigations, to give an opinion.

The other question-how the results of our investigations harmonize with a causal relation between the accumulated metabolic products in the organism and the uraemic symptoms-will now be shortly discussed. It is still uncertain whether the nitrogenous products are the cause of the uraemia or whether the latter is due to unknown substances. Numerous investigations, partly experimental on animals and partly clinical, dealing with the rôle of the various nitrogenous bodies in uraemia, have failed to solve the problem with any degree of certainty. But it is probable that one or more of the bodies is directly responsible for uraemia. If the amount of the various nitrogenous bodies in the blood of our cases be followed daily during the last days or weeks before death, that is, at the time when the clinical symptoms steadily got worse, it will be noticed that the uric acid is considerably increased in all, but in two of the patients it shows no upward tendency, while in patient No. 4 it rises very rapidly in the last week.

Myers has contended that in renal insufficiency the uric acid as a rule is the first of the nitrogenous substances to be retained, as previously mentioned. Our investigations seem to show that in advanced uraemia the uric acid concentration in the blood is not so pronounced as that of the other nitrogenous constituents, which may possibly be due to the fact that the formation of uric acid is normally considerably less than the formation of creatinin, and especially urea, and therefore when the excretory power of the kidney is further reduced the retention of the ereatinin and urea exceeds that of the uric acid. The concentrations of residual $N$, urea $N$, and creatinin, on the other hand, are increased continuously right up till death. In patient No. 3 the amounts of residual $N$ and urea $N$ were decidedly less than in the other patients, the figures being 213 and 200 respectively, while in the three others they were $350-300$ and 280-250 respectively. It is interesting to note the large fraction of the residual $N$ constituted by the urea $\mathrm{N}$ in this patient. It has long been known that with increase of residual $\mathrm{N}$ the percentage of it constituted by urea $\mathrm{N}$ also rises simultaneously. The fact that this relation is particularly well marked in this patient, who died with a lower concentration of residual $\mathrm{N}$ in the blood than the other patients, but in whom the concentration of the nitrogenous bodies in the blood rose more rapidly than in any of the other patients, might indicate that the rate at which this substance increases in the blood intuences the relation between residual $N$ and urea $\mathrm{N}$.

It is well known that death in uraemia can take place with varying quantities of residual $N$ and urea in the blood, but it does not necessarily negative a causal relation between the nitrogenous products and uraemia. The resistance of the 
organism against intoxication may be different, and thus the duration of the intoxication may be important in this connexion. The most constant factor in our patients was the marked increase of creatinin just before death, which agrees with Myers' observation that the amount of creatinin is the best indication of the condition in uraemia.

The alkali reserve in all our patients was diminished sometimes very considerably. In patient No. 4, after the administration of sodium bicarbonate, it rose again to about the physiological concentration and was rougbly normal during the whole of the last month of life, that is to say, at a time when the most important increase of the nitrogenous bodies took place. The fact that death ensues with the typical picture of uraemia while the alkali reserve is absolutely normal-although it was so only in the case of one patient, the others exhibiting a considerable diminution of the alkali reserve-shows that acidosis cannot be of great significance in the aetiology of uraemia.

Our material is too small to allow of any decisive conclusion on the rôle of the retained nitrogenous bodies in the aetiology of uraemia. But the pronounced parallelism there has been in our four patients between the increasing concentrations of the residual $\mathrm{N}$, urea $\mathrm{N}$, and creatinin on the one hand and the clinical symptoms on the other, supports the assumption that there is a causal relation between the retained nitrogenous metabolic products and the clinical symptomcomplex, uraemia.

\section{REFERENCES.}

1. Bang, Ivar, Methoden zur Mikrobestimmung einiger Blutbestandtetle, Wiesbaden, 1916.

2. Folin and Denis, 'On Uric Acid, Urea, and Total Non-protein Nitrogen in Human Blood ', Journ. Biol. Chem., Baltimore, 1913, xiv. 29.

3. Myers, Practical Chem. Analysis of Blood, St. Louis, 1921.

4. Greenwald and McGuire, "The Estimation of Creatinin and Creatin in the Blood', Journ. Biol. Chem., Baltimore, 1918, xxxiv. 103.

5. Folin and Wu, 'A System of Blood Analysis', ibid., 1919, xxxviii. 81.

6. Höst and Hatlehol, 'Blood Sugar Concentration and Blood Sugar Methods', ibid., 1920, xlii. 347.

7. Folin and Denis, 'On the Creatinin and Creatin Content of Blood', ibid., 1914, xvii. 487.

8. Myers, Fine, and Lough, "The Significance of the Uric Acid, Urea, and Creatinin of the Blood in Nephritis', Arch. Int. Med., Chicago, 1916, xvii. 570.

9. Volhard und Fahr, Die Brightsche Nierenkrankheit, 1914.

10. Richter und v. Noorden, see Volhard und Fahr, 1. c., 175.

11. Marshall and Davis, 'Urea: Its Distribution in and Elimination from the Body', Journ. Biol. Chem., Baltimore, 1914, sviii. 53. 